\title{
REVIEW
}

\section{Current trends in the evaluation and management of female urinary incontinence}

\author{
Phillip P. Smith, Rebecca J. McCrery, Rodney A. Appell
}

\section{ABSTRACT}

Despite its common occurrence and often seemingly obvious causes, female urinary incontinence requires a thorough and thoughtful evaluation for its proper diagnosis and treatment. With rare exceptions, urinary incontinence is the result of failure of the sphincter mechanism to resist bladder pressures encountered during daily activities. This may be the result of sphincter failure, overactivity of the bladder detrusor muscle or both. In uncomplicated cases, the diagnosis is usually based on an evaluation in the office. Urodynamic and cystoscopic study may be helpful in complex, resistant and recurring cases of urinary incontinence of any cause. Most cases of incontinence may be classified as stress, urge or mixed urinary incontinence. Treatment of stress urinary incontinence focuses on supplementing the urethral continence mechanisms, particularly the urethral supports and periurethral striated muscle function. The current paradigm for the treatment of urge incontinence centres on pharmacologic therapy, primarily by correcting detrusor overactivity with antimuscarinic drugs. Other therapies aimed at altering sensorimotor function may be used in resistant cases. The treatment of mixed urinary incontinence requires consideration of the contribution of each of its components. With proper diagnosis, effective treatment is possible for most patients.

CMAJ 2006;175(10):1233-40

$\mathrm{U}$ rinary incontinence is a common problem, affecting up to two-thirds of all women. Its prevalence is easily underestimated in the clinical setting, since patients will often fail to bring the condition to the attention of their physician; it is estimated that only I in 4 symptomatic women seek help for this problem. ${ }^{1}$ By recent estimate, the total annual cost of urinary incontinence in the United States is about US\$19.5 billion. ${ }^{2}$ In addition to affecting quality of life, complications of urinary incontinence include urinary retention, chronic lower urinary tract infection and vesicoureteral reflux, all of which affect health greatly. The aim of this review is to give primary care practitioners an overview of the current understanding of the taxonomy, pathophysiology, evaluation and treatment of female urinary incontinence.

\section{Pathophysiology}

Patients present with symptoms rather than diagnoses - an important distinction in the discussion of female urinary incontinence. Most patients with any degree of urinary incontinence will have symptoms that point to stress incontinence, urge incontinence or mixed incontinence. The symptom of stress urinary incontinence is the involuntary loss of urine accompanying sudden increases in intra-abdominal pressure (i.e., "stress"); this loss is sudden, coincident with the stressor and usually without warning. Urge incontinence occurs when an overwhelming urge to void results in leakage of urine; about half of all patients with overactive bladder syndrome experience urge incontinence. ${ }^{3}$ Mixed incontinence is the concurrence of stress and urge incontinence symptoms.

As the bladder fills, sensory afferent signals are carried via the pelvic and hypogastric nerves to the spinal cord (Fig. I), where they are relayed to the pontine micturition centre via the lateral spinothalamic tracts and dorsal columns. Sympathetic tonus via the hypogastric nerve maintains smooth musclebased activity of the urethral sphincter and aids in detrusor relaxation, which thus promotes urine storage. Somatic efferent signals to the striated muscle of the pelvic floor via the pudendal nerve provide voluntary urethral sphincter activity, as well as momentary augmentation of urethral resistance in response to sudden increases in bladder pressure. As afferent signaling increases in intensity with bladder filling, a threshold of consciousness is reached, at which point a socially appropriate opportunity to void is sought. With permission to void, pontine signaling to the sacral cord via reticulospinal and corticospinal tracts results in parasympathetic cholinergic activation of the detrusor and reflex relaxation of the striated muscle of the pelvic floor, which allows pressurized urine flow. ${ }^{4}$

Neurologic insults commonly cause involuntary detrusor contractions and urinary incontinence by interrupting the pathways that control and coordinate the micturition reflex. Although lesions and conditions may vary in their effect on voiding dysfunction and incontinence, central nervous system lesions at or above the thoracic spine often result in inappropriate detrusor activity, poor coordination of detrusor and sphincter activity, or both. Lesions below this level, including peripheral lesions, often result in an areflexic detrusor. In all cases, lower urinary tract symptoms, including urinary incontinence, may result., 
The diagnosis of stress urinary incontinence implies failure of sphincter function. Normal function depends on factors that are both intrinsic and extrinsic to the urethra. Intrinsic factors include normal urethral mucosal and smooth-muscle function. These, in turn, are related to estrogen status, tissue and genetic factors, and any prior urethral disease or manipulation that may have disturbed the normal urethral epithelium and tissue compliance. Extrinsic factors are primarily the relatively static pubourethral ligamentous support and the dynamic function of the striated muscle of the pelvic floor. These factors undoubtedly assume varying degrees of importance in the individual continent woman and, in balance, provide sufficient resistance to sudden increases in intra-abdominal pressure. Stress urinary incontinence occurs when the sum of these factors is inadequate for normal sphincter function. The integral theory of female urinary incontinence, which was introduced by Petros and Ulmsten in 1990, 7 proposes that stress incontinence arises from laxity of the pubourethral ligaments and anterior vaginal wall. This is the dominant therapeutic model at present.

Urge urinary incontinence results from some combination of detrusor overactivity, detrusor or urothelial hypersensitivity

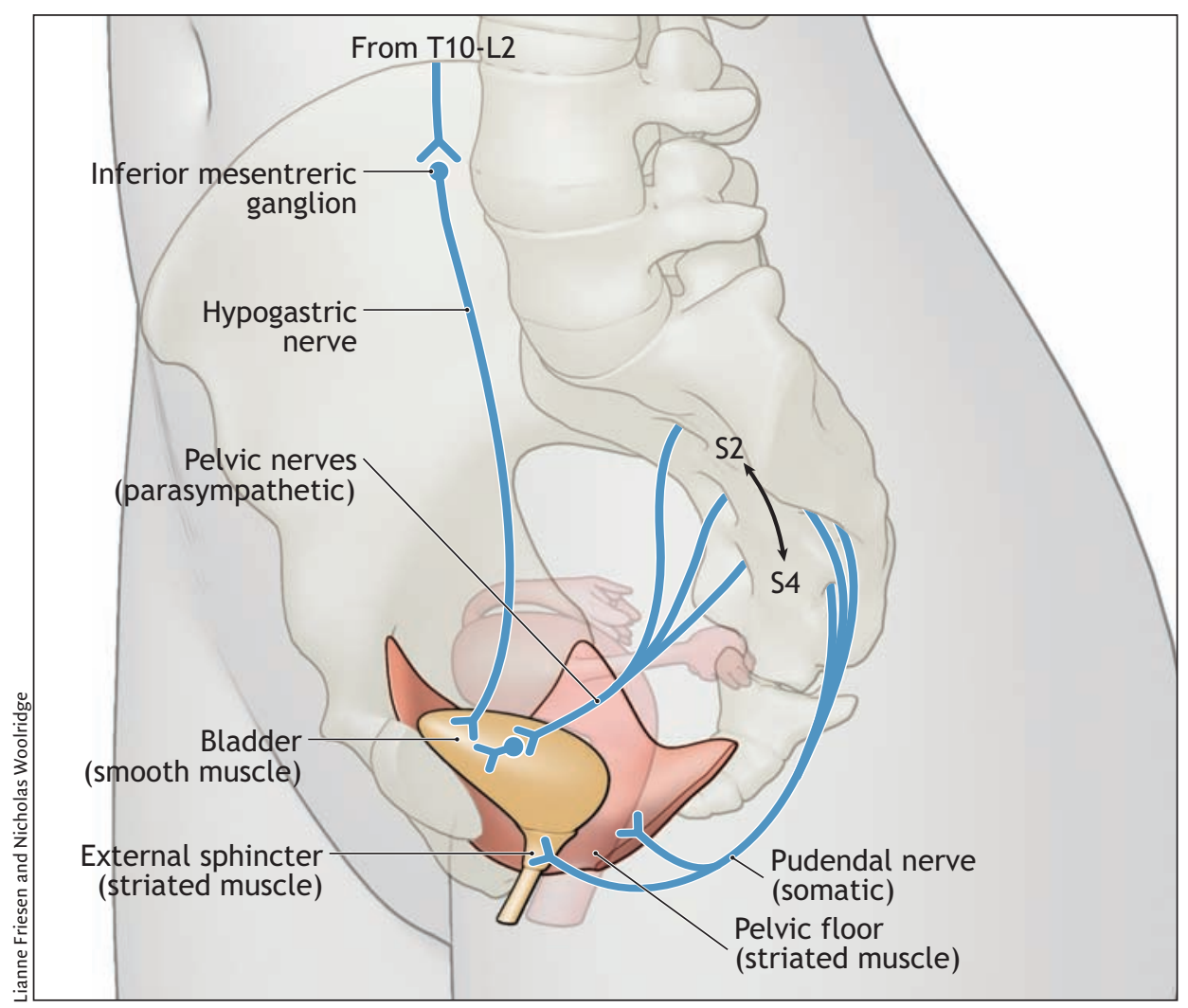

Fig. 1: Neuroanatomy of the lower urinary tract. During urine storage, the bladder is relaxed and the urethral smooth muscle maintains basal tonus, under the influence of sympathetic outflow via the hypogastric nerve. Somatic efferent signals via the pudendal nerve to the striated muscle of the pelvic floor and urethra provide voluntary urethral sphincter activity, of particular importance with sudden increases in intra-abdominal pressure. During voiding, parasympathetic cholinergic activation via the pelvic nerves results in contraction of the detrusor and reflex relaxation of the striated muscle of the pelvic floor, which allows pressurized urine flow. and poor detrusor-sphincter coordination. Although the symptoms suggest detrusor motor overactivity, the cause may be sensory dysfunction or urodynamically demonstrable motor overactivity or both. For the patient with urge incontinence, disordered sensory or motor function results in unintended detrusor activity, which overcomes urethral resistance.

\section{Evaluation}

Lower urinary tract symptoms are poor predictors of the underlying diagnosis of urinary incontinence. ${ }^{8}$ Both stress and urge incontinence symptoms may have sphincter, bladder, neuromuscular and cognitive origins. The goal of evaluation is to identify the diagnosis underlying the incontinence symptoms. Effective therapy may then be selected.

History and physical examination are crucial. Certain medications may contribute to urinary incontinence by the following mechanisms: ${ }^{9}$

- Decreased urethral pressure ( $\alpha$-adrenergic blockers, neuroleptics, benzodiazepines)

- Increased bladder pressure, muscular effects (bethanechol, cisapride)

- Increased bladder pressure, volume of urine (diuretics)

- Increased bladder pressure, impaired voiding (anticholinergics, antiparkinsonism agents, $\beta$ blockers, disopyramide)

- Indirect effects: cough (angiotensin-converting-enzyme inhibitors), constipation (iron, narcoleptics), mental status changes (psychotropics)

In addition, many medical conditions may directly affect bladder function and must be considered in the evaluation; a partial list is given in Box I. During the physical examination, the physician must look for objective evidence of involuntary urine loss, document detrusor function sufficient to empty the bladder, assess the sphincter mechanism, both intrinsic and extrinsic to the urethra, and discover any evidence of other causes (e.g., fistulas) of, or contributors (e.g., infection) to, urinary incontinence. Urethral mobility should be assessed objectively, for example, by the "Q-Tip" test. ${ }^{10}$ In this test, a sterile cotton swab is inserted through the urethra into the bladder and withdrawn just until the resistance of the bladder neck is felt. The patient is asked to bear down and the change in angle of the swab is noted. Angles greater than $30^{\circ}$ indicate urethral hypermobility. Vaginal prolapse 
should be assessed, as prolapse of the anterior vagina to or beyond the introitus may result in "paradoxical continence," in which poor sphincter function is masked by the pinching-off of the bladder neck by the prolapse. Although vaginal prolapse and hypermobility are often associated with incontinence, neither is the cause. ${ }^{11}$ Table I summarizes a stepwise approach to the physical examination and the relation of the various assessments to the causes of urinary incontinence.

The question of when to obtain multichannel urodynamic evaluation has no clear answer. The purpose of urodynamic study is to reproduce patient symptoms in a monitored setting; therefore, urodynamic studies are recommended when the history and clinical examination are insufficient to reach a diagnosis. It is unclear whether routine urodynamic study significantly helps in the treatment of stress urinary incontinence. ${ }^{12}$ Therefore, a woman with no prior pelvic surgery who is found to have a hypermobile urethra and urine loss coincident with stress or strain probably does not require urodynamic study. However, patients in whom empiric nonsurgical therapy or surgical treatment has failed, those who have elevated post-void residual volumes and patients who have complex symptoms, history or examination findings deserve urodynamic study. Consideration should be given to urodynamic examination of patients with urge or mixed incontinence symptoms, since the cause of these symptoms may be complex and misleading. ${ }^{13}$ A significant proportion of women with symptoms of urge incontinence are found to have stress urinary incontinence ${ }^{14}$ and therefore would presumably receive improper treatment if therapy were determined in the absence of urodynamic study.

Urodynamic study is subjective since it requires interaction between the patient and the observer, and urodynamic data are poorly reproducible. ${ }^{15}$ Therefore, the test is perhaps best conducted by the physician who will interpret the results.

\section{Treatment of common causes of urinary incontinence}

\section{Stress incontinence}

Table 2 summarizes the recommended treatment of stress urinary incontinence. Effective treatment requires a proper diagnosis of the condition. The choice of treatment is limited to physiotherapy and procedural interventions. Pelvic-floor training consisting of repetitive contraction of the levator muscles (usually referred to as Kegel exercises) is the cornerstone of physiotherapy and may be taught by a physician or nurse. Specialized practitioners offer more intensive instruction and biofeedback. Short-term improvements in most women with stress urinary incontinence have been reported, and longerterm success appears to be related to continuing the pelvicfloor training program. ${ }^{16,17}$ A Cochrane review ${ }^{18}$ concluded that physiotherapy is effective, but its therapeutic role when compared with other modalities is difficult to assess owing to study limitations. Because of the lack of risk and relatively small cost, an initial trial of physiotherapy is appropriate if the patient is willing to participate actively in her treatment.
Box 1: Possible effects of medical conditons on bladder function

Impaired neuromuscular function or tissue integrity

- Parity and vaginal birth

- Prior pelvic surgery

Impaired sensorimotor function

- Diabetes mellitus

- Neurologic disease

Parkinsonism

Cerebrovascular accident

Multiple sclerosis

Spinal cord injury

Congenital defect

Abnormal stressors (volume, pressure)

- Congestive heart failure

- Chronic obstructive pulmonary disease

Cognitive impairment or failure of voluntary bladder control

- Dementia

- Psychiatric disease

Pharmacologic therapy with the serotonin-norepinephrine reuptake inhibitor duloxetine has been investigated. This drug is believed to enhance pudendal nerve stimulation of the pelvic floor. It has been shown to alleviate symptoms of stress urinary incontinence in several randomized controlled studies, and its effects appear to be synergistic with pelvic-floor training. ${ }^{19}$ However, because women using duloxetine had a 2 -fold increase in suicide risk compared with the general population - an effect not seen in its use for treatment of depression the US Food and Drug Administration denied approval of the drug for the treatment of stress urinary incontinence. ${ }^{20}$

Injection of a bulking agent into the submucosal or periurethral tissues or both is effective and minimally invasive. In a recent review of the history and current state of injection therapy, Chapple and colleagues ${ }^{21}$ concluded that therapy with currently available agents is safe and effective, regardless of urethral mobility or urodynamic assessments of urethral function, and therefore may be considered as a first-line treatment for uncomplicated stress incontinence. There are no data indicating the superiority of any particular agent, although collagen must be regarded as temporary because the substance degrades over time. Injection therapy is not as effective as surgery, whether measured in terms of objective cure or improved quality of life; however, it presents fewer risks to the patient. ${ }^{21,22}$ Although a recent randomized prospective study showed total I-year costs of injection therapy to be greater than surgery costs, ${ }^{23}$ there are insufficient data on which to base cost comparisons. ${ }^{21}$

Surgery for stress urinary incontinence can be broadly categorized into retropubic operations, bladder-neck slings and tension-free, midurethral slings. Although the first 2 categories have been practised for decades, retropubic midurethral slings were introduced in $1996 .{ }^{24}$ Their wide applicability and technical simplicity have led to their widespread use, and they have become the preferred surgical treatment of stress incontinence 
by most surgeons. ${ }^{25}$ Traditional retropubic operations (e.g. Burch colposuspension or Marshall-Marchetti-Krantz anterior cystourethropexy) and bladder-neck slings remain the standards to which others are compared, and both have been the subjects of recent Cochrane reviews. ${ }^{26,27}$

Tension-free, midurethral slings are intended to stabilize the midurethra, based on the integral theory of sphincter function (Fig. 2). Therefore, this technique would seem to be most appropriate for patients with urethral hypermobility, since this probably indicates loss of pubourethral support. Two recent re-

\begin{tabular}{|c|c|c|c|}
\hline Step & $\begin{array}{c}\text { Test or } \\
\text { examination }\end{array}$ & Assessment & Causal factor \\
\hline \multirow[t]{2}{*}{1} & \multirow[t]{2}{*}{ Urinalysis } & Infection & Detrusor and sphincter dysfunction \\
\hline & & Hematuria & Internal bladder lesion \\
\hline 2 & $\begin{array}{l}\text { General } \\
\text { condition }\end{array}$ & Mobility, cognition & Volitional aspects of continence \\
\hline 3 & $\begin{array}{l}\text { Neurologic } \\
\text { examination }\end{array}$ & Reflexes & $\begin{array}{l}\text { Sensory and motor nerve and } \\
\text { spinobulbar function }\end{array}$ \\
\hline \multirow[t]{3}{*}{4} & \multirow{3}{*}{$\begin{array}{l}\text { Pelvic } \\
\text { examination }\end{array}$} & Mass, tenderness & Inflammation, compression \\
\hline & & Vaginal prolapse & Extrinsic urethral sphincter function \\
\hline & & Vaginal examination & Non-urethral leakage \\
\hline 5 & “Q-Tip" test & Urethral mobility & Extrinsic urethral sphincter function \\
\hline 6 & Catheterization & Post-void volume & Detrusor, outlet adequacy \\
\hline \multirow[t]{3}{*}{7} & \multirow[t]{3}{*}{ Urodynamic study } & Urine flow & $\begin{array}{l}\text { Obstruction, intrinsic sphincter } \\
\text { function }\end{array}$ \\
\hline & & Cystometrogram & Detrusor and sensory dysfunction \\
\hline & & Electromyogram & Extrinsic urethral sphincter function \\
\hline \multirow[t]{3}{*}{8} & \multirow[t]{3}{*}{ Cystoscopy } & Urothelium & Urothelial abnormalities, fistulas \\
\hline & & $\begin{array}{l}\text { Detrusor } \\
\text { trabeculation }\end{array}$ & Chronic obstruction \\
\hline & & Urethra & Diverticulas, inflammation, fistulas \\
\hline
\end{tabular}

Table 2: Treatment options for stress urinary incontinence*

\begin{tabular}{|c|c|c|c|c|}
\hline Treatment & $\begin{array}{l}\text { Effectiveness } \\
\text { in the presence } \\
\text { of urethral } \\
\text { hypermobility }\end{array}$ & $\begin{array}{l}\text { Effectiveness } \\
\text { in the absence } \\
\text { of urethral } \\
\text { hypermobility }\end{array}$ & Cost & Risk \\
\hline \multicolumn{5}{|c|}{$\begin{array}{l}\text { Appropriate for primary care } \\
\text { physician to order or provide }\end{array}$} \\
\hline Physiotherapy & $+\dagger$ & $+/-\dagger$ & + & - \\
\hline \multicolumn{5}{|l|}{$\begin{array}{l}\text { Requiring specialist referral } \\
\text { or consultation }\end{array}$} \\
\hline Injection of bulking agent & +++ & +++ & $++/+++$ & + \\
\hline Burch colposuspension & ++++ & ++ & ++++ & +++ \\
\hline Paravaginal repair & ++ & + & ++++ & +++ \\
\hline Bladder-neck sling & ++++ & ++++ & ++++ & +++ \\
\hline Midurethral sling & ++++ & +++ & ++++ & +++ \\
\hline
\end{tabular}

*The rating system of 1 to 4 plus signs (from least to most) is to be interpreted as an approximate guide and does not imply direct proportionality between treatments or categories.

†Effectiveness depends on patient compliance. views of 2-6-year follow-up data found cure rates among patients with midurethral slings to be comparable to those among women with Burch urethropexy and fascial bladderneck slings. ${ }^{28,29}$ Urodynamic data, such as urethral pressure profiles and leak point pressures, are more likely of value in terms of a prognosis than as firm decision points in the choice of operation. ${ }^{28}$ The newer transobturator approach to placement of the midurethral sling has been shown to be as effective as the original retropubic placement, and to have fewer complications. ${ }^{30-32}$ Because this technique was introduced in 200I, no long-term data are available regarding durability or suitability for use in specific circumstances.

\section{Urge incontinence}

Treatment of urge incontinence is summarized in Table 3. Empiric therapy may be instituted in otherwise uncomplicated cases. However, any findings suggestive of organic pathology (e.g., abnormal urinalysis results, bladder tenderness or a pelvic mass) require thorough investigation before treatment. Complex cases and empiric trial failures should be referred for more extensive evaluation.

The current paradigm for the treatment of urge incontinence is to reduce undesired detrusor activity through reversible blockade of the muscarinic receptors at the detrusor neuromuscular junction. Table 4 shows the drugs available for use in antimuscarinic therapy.

Five subtypes of muscarinic receptors have been identified; $M_{2}$ and $M_{3}$ receptors are the predominate subtypes found in the bladder. $M_{3}$ receptors are primarily responsible for bladder contractility. ${ }^{33}$ Their ubiquity in the human body results in a high incidence of side effects from blocking agents. The therapeutic objective of bladder $\mathrm{M}_{3}$ blockade with antimuscarinic agents is often limited by the anticholinergic side effects resulting from blockade of muscarinic receptors in other tissues, such as salivary glands, lacrimal glands, the gastrointestinal tract and the central nervous system.

Immediate-release oxybutynin was the first dedicated antimuscarinic agent for the treatment of overactive bladder symptoms, including urge incontinence. The antimuscarinic drugs currently available in the United States are oxybutynin (immediate and extended release, and transdermal), tolterodine (immediate and extended release), trospium chloride (immediate release), solifenacin (extended release) and 
darifenacin (extended release). Comparisons to placebo and head-to-head comparisons of the available antimuscarinic drugs are incomplete, with nonstandardized study designs, outcome measures and choice of preparations to be compared.

A recent meta-analysis suggested that immediate-release tolterodine is associated with a lower risk of dry mouth than is immediate-release oxybutynin; however, the extendedrelease preparations of both oxybutynin and tolterodine are associated with less dry mouth than either immediate-release formulation. ${ }^{35}$ The results of the OPERA trial, comparing the extended-release fixed-dose formulations of oxybutynin (Io $\mathrm{mg}$ ) and tolterodine (4 mg), found similar reductions in the number of weekly episodes of urge urinary incontinence and of total incontinence episodes in the 2 groups. Micturition frequency and the proportion of women reporting no incontinent episodes was lower in the oxybutynin group, although more reported dry mouth. ${ }^{34}$

Studies comparing transdermal oxybutynin with the immediate-release formulations of tolterodine and oxybutynin have shown similar efficacy results. ${ }^{36,37}$ The transdermal oxybutynin formulation is associated with less dry mouth. The first-pass metabolism in the liver is avoided, which results in decreased production of the primary metabolite, $N$-desethyloxybutynin, which is associated with xerostomia. Application-site reactions are the cause of discontinuation of the transdermal medication in up to $10 \%$ of patients. ${ }^{38}$

The STAR study ${ }^{39}$ compared 2 newer antimuscarinic medications: solifenacin succinate ( $5 \mathrm{mg}$ or $\mathrm{Io} \mathrm{mg}$ ) and extendedrelease tolterodine ( $4 \mathrm{mg}$ ) in 1200 patients. The conclusion was that the flexible dosing regimen of solifenacin was more efficacious than tolterodine in decreasing urgency episodes, incontinence, urge incontinence and pad use and in increasing the volume voided per micturition. Discontinuation rates owing to adverse effects were similarly low in both groups. The long half-life of solifenacin may be an important factor contributing to its improved efficacy.

Trospium chloride was recently approved for use in the United States, although it has been safely used in Europe for over 20 years. ${ }^{40}$ It is unique in that it is a quaternary amine, which prevents it from crossing the blood-brain barrier, and more than $60 \%$ of the active compound is excreted unchanged in the urine. Complete continence was attained in only $2 \mathrm{I} \%$ of patients given trospium in a placebo-controlled trial. ${ }^{41}$

Darifenacin is another novel antimuscarinic agent in that it is the first approved agent that is selective for the $M_{3}$ muscarinic receptor. Laboratory evidence also suggests that it is more selective for the $M_{3}$ receptors of the bladder than for those of the salivary glands, ${ }^{40,42}$ although the clinical significance of these animal data remains unknown.

Overall, no one anticholinergic drug is better than another for treating symptoms of overactive bladder in adults. Except for immediate-release oxybutynin, all antimuscarinic drugs are generally well tolerated, and contraindications are few. Unfortunately, long-term patient compliance with medications for overactive bladder and urinary incontinence is poor. In a recent study involving 2496 patients, as many as $36.9 \%$ had not refilled their initial prescription during a 6-month follow-up period. ${ }^{43}$ Another study showed that about $80 \%$ of patients with overactive bladder stopped their medications within 6 months. ${ }^{44}$ In yet another study, patients who did refill their prescriptions were

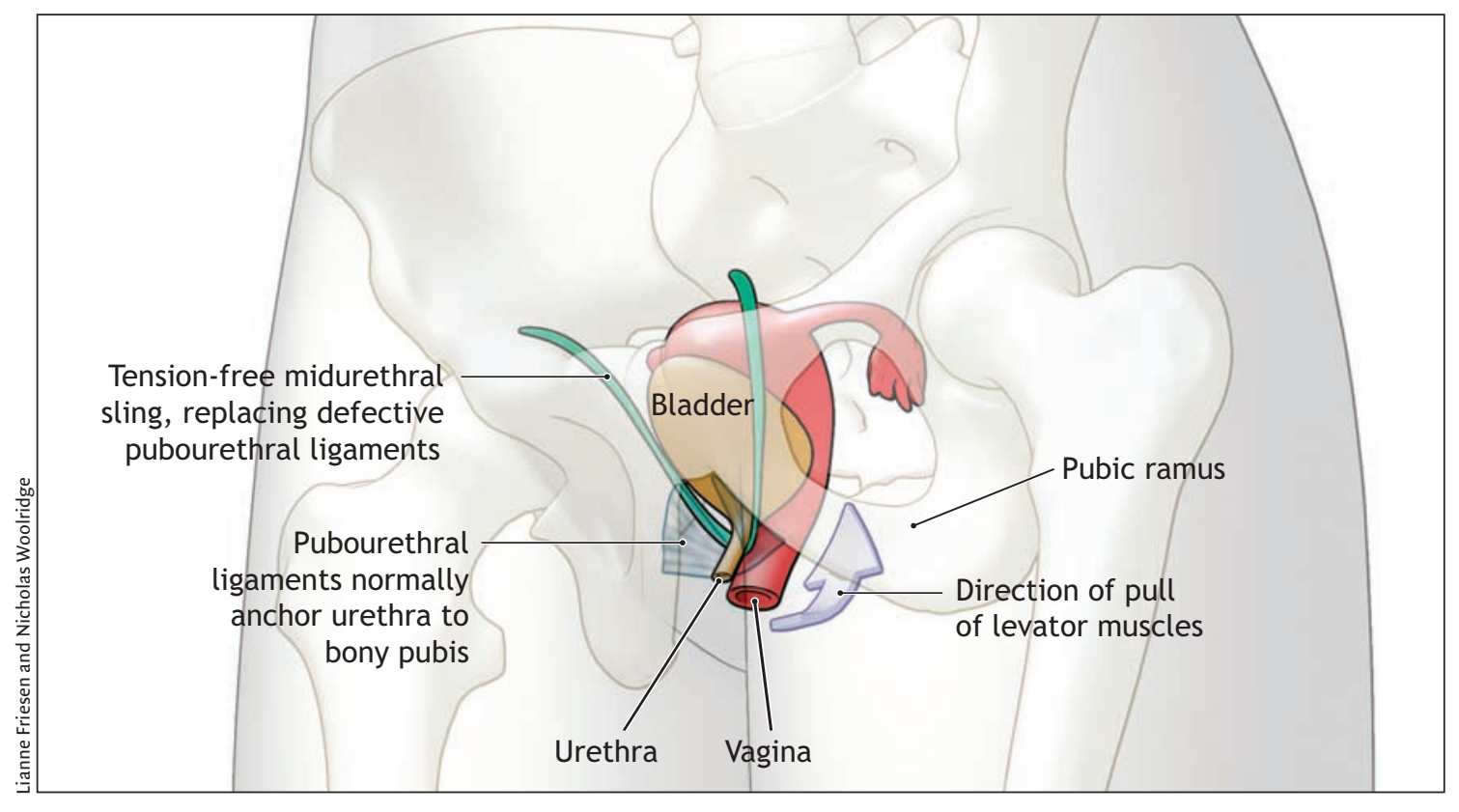

Fig. 2: Action of tension-free midurethral sling in the treatment of stress urinary incontinence in women. The anterior pubourethral ligaments stabilize the distal urethra when the levator muscles contract, for example during coughing or straining. This action stretches the urethra along its axis, which results in increased resistance to urine flow. Damaged pubourethral ligaments result in urethral hypermobility and poor anchoring; thus, the levator action cannot alter the urethral tension. Tension-free midurethral slings seek to reproduce this stabilizing/ fulcrum action of the pubourethral ligaments. 
found to take their medications only about a third of the time. ${ }^{43}$ Therefore, drug levels are not maintained and patients are not benefiting from the maximum effect of the medications.

Although efficacy is generally comparable among all agents, the results and side effects in individual patients are variable. Failure to respond to or intolerance of one drug does not indicate a failure of antimuscarinic therapy. Another antimuscarinic agent will often be found to be effective and well tolerated.

Other pharmacologic approaches have been considered for the management of urge incontinence. The use of topical or systemic estrogen therapy remains controversial. A Cochrane review of estrogens for urinary incontinence in women ${ }^{45}$ indicated that, compared with placebo, estrogen use resulted in higher rates of cure and symptom improvement, with more positive effects on urge incontinence than on stress incontinence. The concomitant use of progestins may decrease the amount of improvement. Flavoxate hydrochloride,${ }^{46}$ propiverine and imipramine are other medications that have been used in clinical practice for incontinence; however, consistent data supporting their effectiveness in this area are minimal. Desmopressin acetate, an analogue of antidiuretic hormone that decreases urine production by increasing water reabsorption in the collecting tubules of the kidneys, has been useful when nocturia is a major complaint. ${ }^{47,48}$ Intradetrusor injection of botulinum A toxin has also been useful for the treatment of detrusor motor activity and other functional disorders of the lower urinary tract. ${ }^{49,50}$

Nonpharmacologic treatment may be helpful, although it will usually require referral to the appropriate specialist. Physical therapy techniques, such as bladder training, pelvic-floor exercises and electrical stimulation of the pelvic floor, have all

Table 3: Treatment options for urge urinary incontinence*

\begin{tabular}{|c|c|c|}
\hline Treatment & Effectiveness & Cost \\
\hline \multicolumn{3}{|l|}{$\begin{array}{l}\text { Appropriate for primary care } \\
\text { physician to order or provide }\end{array}$} \\
\hline Physiotherapy & + & + \\
\hline $\begin{array}{l}\text { Biofeedback with or without } \\
\text { pelvic-floor electrical stimulation }\end{array}$ & + & ++ \\
\hline Acupuncture & + & ++ \\
\hline $\begin{array}{l}\text { Anticholinergic or antimuscarinic } \\
\text { therapy (uncomplicated cases) }\end{array}$ & ++ & ++ \\
\hline \multicolumn{3}{|l|}{$\begin{array}{l}\text { Requiring specialist referral } \\
\text { or consultation }\end{array}$} \\
\hline $\begin{array}{l}\text { Anticholinergic or antimuscarinic } \\
\text { therapy (complicated cases) }\end{array}$ & ++ & ++ \\
\hline Sacral nerve stimulation & ++ & +++ \\
\hline $\begin{array}{l}\text { Intravesical therapy (oxybutynin, } \\
\text { atropine, trospium, capsaicin, } \\
\text { resiniferatoxin) }\end{array}$ & ++ & +++ \\
\hline Botulinum A toxin & ++ & +++ \\
\hline Augmentation cystoplasty & ++ & ++++ \\
\hline Denervation procedures & ++ & ++++ \\
\hline
\end{tabular}

been studied. The results of a meta-analysis examining the effects of conservative treatment of urge incontinence suggested that these physical therapies have a favourable effect on patients with this problem. ${ }^{51}$ Although long-term data regarding their efficacy are scarce, these options have minimal side effects, do not exclude future treatment options and may be useful as an adjunct to other therapies. Unfortunately, long-term patient adherence to these programs is poor. ${ }^{52}$ More direct neuromodulatory techniques, such as acupuncture and sacral nerve stimulation, have demonstrated success in relieving symptoms, although urodynamic data have not been as impressive. ${ }^{53-56}$ Surgical intervention, such as bladder augmentation, may rarely be required in patients with refractory urge incontinence and should be considered only after a comprehensive evaluation and failure of more conservative therapies.

\section{Mixed incontinence}

At least one-third of patients with urinary incontinence have a mixture of stress and urge incontinence. This mixed incontinence implies dysfunction both in sensorimotor control of the detrusor and in the sphincter mechanism. Urodynamic study is particular helpful in the evaluation of mixed incontinence. Obvious causes of either the urge or stress component of incontinence should be addressed.

Given the relatively low costs and risks, an initial trial of medical or behavioural therapy, or both, directed at the urge component has been recommended as the first step in treat-

Table 4: Drugs used in antimuscarinic therapy

\begin{tabular}{|c|c|c|}
\hline Drug & Dose & Comments \\
\hline \multicolumn{3}{|l|}{ Oxybutynin } \\
\hline Extended-release & $\begin{array}{l}5-30 \mathrm{mg} \\
\text { once daily }\end{array}$ & $\begin{array}{l}\text { Effectiveness and side } \\
\text { effects comparable to } \\
\text { those of tolterodine }\end{array}$ \\
\hline Immediate-release & $\begin{array}{l}2.5-5 \mathrm{mg} \\
3 \text { times daily }\end{array}$ & $\begin{array}{l}\text { The "gold standard"; } \\
\text { high incidence of side } \\
\text { effects }\end{array}$ \\
\hline Transdermal & $\begin{array}{l}3.9 \mathrm{mg} \\
\text { twice weekly }\end{array}$ & $\begin{array}{l}\text { Alternative delivery } \\
\text { system avoids hepatic } \\
\text { first-pass effect }\end{array}$ \\
\hline \multicolumn{3}{|l|}{ Tolterodine } \\
\hline Long-acting & $\begin{array}{l}2-4 \mathrm{mg} \\
\text { once daily }\end{array}$ & $\begin{array}{l}\text { More selective for the } \\
\text { bladder over the } \\
\text { salivary gland in vitro }\end{array}$ \\
\hline Immediate-release & $\begin{array}{l}1-2 \mathrm{mg} \\
\text { twice daily }\end{array}$ & $\begin{array}{l}\text { More selective for the } \\
\text { bladder over the } \\
\text { salivary gland in vitro }\end{array}$ \\
\hline Trospium chloride & $\begin{array}{l}20 \mathrm{mg} \\
\text { twice daily }\end{array}$ & $\begin{array}{l}\text { Quaternary amine } \\
\text { minimizes CNS effects }\end{array}$ \\
\hline Solifenacin & $\begin{array}{l}5-10 \mathrm{mg} \\
\text { once daily }\end{array}$ & $\begin{array}{l}\text { Longer half-life may } \\
\text { improve results. }\end{array}$ \\
\hline Darifenacin & $\begin{array}{l}7.5-15 \mathrm{mg} \\
\text { once daily }\end{array}$ & $\begin{array}{l}\text { Detrusor } \mathrm{M}_{3} \text {-receptor } \\
\text { specific; less cognitive } \\
\text { impairment than other } \\
\text { agents }\end{array}$ \\
\hline
\end{tabular}

Note: CNS = central nervous system. 
ment. ${ }^{57}$ Anticholinergic therapy has been associated with at least some improvement in symptoms in most trials. Alternatively, initial therapy may be chosen on the basis of the patient's predominant symptoms..$^{58}$ According to the integral theory of incontinence, urge incontinence arises from abnormal sensations resulting from loss of pubourethral support and is therefore a surgical problem. In fact, there are no comparative data to suggest that midurethral slings are effective in the treatment of the urge component. Not surprisingly, in one study, intrinsic urethral dysfunction was associated with poorer outcomes in the relief of urge symptoms among patients who underwent placement of a midurethral sling to treat the stress component. ${ }^{59}$ Although mixed incontinence has been perceived to be less amenable to treatment than either stress or urge incontinence alone, careful evaluation and choice of therapy should result in cure rates similar to those associated with urge or stress incontinence. ${ }^{58}$

\section{Other causes of urinary incontinence}

We have focused this review on the evaluation and management of stress, urge and mixed urinary incontinence. Although most patients with urinary incontinence fall into one of these categories, there are 2 notable extra-urethral causes of incontinence to be considered: fistulas and congenital ectopic ureter. Both conditions commonly present as total urinary incontinence, although they may masquerade as stress or urge incontinence, and neither responds to medical or surgical measures aimed at treating stress or urge incontinence.

Fistulas completely bypass the normal sphincter mechanism and result in total incontinence. In patients with urinary incontinence who have a history of pelvic surgery or difficult vaginal birth, a vesicovaginal fistula should be considered in the evaluation. Ectopic ureter should be considered in patients with life-long incontinence.

\section{Conclusions}

Female urinary incontinence is common and amenable to therapy in most cases. Currently available treatment options can be expected to give satisfactory relief to up to $90 \%$ of patients. Thoughtful evaluation resulting in a supportable diagnosis is essential before commencing therapy. Primary care physicians should ask their female patients about urinary incontinence and be prepared to evaluate and treat the condition or, if necessary, refer the patient to the appropriate specialist. Practitioners must consider a wide range of causes when confronted with an apparently straightforward case if therapy is to provide maximum benefit with the least risk to the patient.

\section{This article has been peer reviewed.}

From the Division of Voiding Dysfunction and Female Urology, Scott Department of Urology, Baylor College of Medicine, Houston, Tex.

Competing interests: None declared for Phillip Smith and Rebecca McCrery. Rodney Appell is a consultant with Boston Scientific Corporation and has received honoraria from Pfizer, Ortho-McNeil, Watson Pharmaceuticals, Astellas Pharma, Novartis Pharmaceuticals, Esprit Pharma and Indevus Pharmaceuticals for talks on overactive bladder treatment.
Contributors: All of the authors agreed on the approach to this topic. Phillip Smith wrote the abstract, researched and wrote the sections on stress urinary incontinence and mixed incontinence and associated tables, contributed to the writing of the introductory section and assembled the initial draft. Rebecca McCrery researched and wrote the section on urge urinary incontinence and associated tables and contributed to the introductory section. Rodney Appell provided guidance regarding the depth of content, key articles to include and revisions, and revised the manuscript for intellectual content. All of the authors approved the submitted version of the manuscript.

\section{REFERENCES}

I. Nygaard IE, Heit M. Stress urinary incontinence. Obstet Gynecol 2004;104:607-20.

2. Hu TW, Wagner TH, Bentkover JD, et al. Costs of urinary incontinence and overactive bladder in the United States: a comparative study. Urology 2004;63:46I-5.

3. Wein AJ, Rovner ES. Definition and epidemiology of overactive bladder. Urology 2002;60(suppl):7-I2.

4. Serels SR, Appell RA. Contemporary diagnosis and management of bladder control problems. Newtown (PA): Handbooks in Health Care; 2005. p. I4-8.

5. Blaivas JG. Pathophysiology of lower urinary tract dysfunction. Urol Clin North Am I985;12:215-24.

6. Partoll LM. Voiding dysfunction and retention. In: Walters MD, Karram MM, editors. Urogynecology and reconstructive pelvic surgery. St Louis: Mosby; I996. p. 329-40.

7. Petros P, Ulmsten U. An integral theory of female urinary incontinence. Experimental and clinical considerations [review]. Acta Obstet Gynecol Scand Suppl I990;I53:7-3I.

8. Blaivas JG. The bladder is an unreliable witness. Neurourol Urodyn I996;15:443-5.

9. Steele AC, Kohli N, Mallipeddi P, et al. Pharmacologic causes of female incontinence. Int Urogynecol J Pelvic Floor Dysfunct I999; Io(2):106-10.

Io. Crystle CD, Charme LS, Copeland WE. Q-Tip test in stress urinary incontinence. Obstet Gynecol I971;38:313-5.

II. Smith PP, Appell RA. Pelvic organ prolapse and the lower urinary tract: the relationship of vaginal prolapse to stress urinary incontinence. Curr Urol Rep 2005;6:340-7.

I2. Heesakkers JPFA, Vriesema JLJ. The role of urodynamics in the treatment of lower urinary tract symptoms in women. Curr Opin Urol 2005;15:215-21.

I3. Lin LY, Yeh NH, Lin CY, et al. Comparisons of urodynamic characteristics between female patients with overactive bladder and overactive bladder plus stress urinary incontinence. Urology 2004;64:945-9.

I4. Digesu GA, Khullar V, Cardozo L, et al. Overactive bladder symptoms: Do we need urodynamics? [published erratum appears in Neurourol Urodyn 2003;22:356]. Neurourol Urodyn 2003;22:105-8.

I5. Gupta A, Defreitas G, Lemack GE. The reproducibility of urodynamic findings in healthy female volunteers: results of repeated studies in the same setting and after short-term follow-up. Neurourol Urodyn 2004;23:31I-6.

I6. Bo K, Talseth T, Holme I. Single blind, randomised controlled trial of pelvic floor exercises, electrical stimulation, vaginal cones, and no treatment in management of genuine stress incontinence in women. BMJ I999;318:487-93.

17. Neumann PB, Grimmer KA, Grant RE, et al. The costs and benefits of physiotherapy as first-line treatment for female stress urinary incontinence. Aust N Z J Public Health 2005;29:4I6-2I.

I8. Hay-Smith J, Herbison P, Ellis G, et al. Which anticholinergic drug for overactive bladder symptoms in adults [review]. Cochrane Database Syst Rev 2005;(3):CDo05429.

I9. Ghoniem GM, van Leeuwen JS, Elser DM, et al. A randomized controlled trial of duloxetine alone, pelvic floor muscle training alone, combined treatment and no active treatment in women with stress urinary incontinence. JUrol 2005;173:1647-53.

20. Lenzer J. FDA warns that antidepressants may increase suicidality in adults. $B M J$ 2005;331:70.

2I. Chapple CR, Wein AJ, Brubaker L, et al. Stress incontinence injection therapy: what is best for our patients? Eur Urol 2005;48:552-65.

22. Corcos J, Collet JP, Shapiro S, et al. Multicenter randomized clinical trial comparing surgery and collagen injections for treatment of female stress urinary incontinence. Urology 2005;65:898-904.

23. Maher CF, O'Reilly BA, Dwyer PL, et al. Pubovaginal sling versus transurethral Macroplastique for stress urinary incontinence and intrinsic sphincter deficiency: a prospective randomised controlled trial. BJOG 2005;II2:797-80I.

24. Ulmsten U, Henriksson L, Johnson P, et al. An ambulatory surgical procedure under local anesthesia for treatment of female urinary incontinence. Int Urogynecol) Pelvic Floor Dysfunct i $996 ; 7: 8 \mathrm{I}-5$.

25. Jha S, Arunkalaivanan AS, Davis J. Surgical management of stress urinary incontinence: a questionnaire based survey. Eur Urol 2005;47:648-52.

26. Bezerra CA, Bruschini H, Cody DJ. Traditional suburethral sling operations for urinary incontinence in women [review]. Cochrane Database Syst Rev 2005;(3):CDooI754.

27. Lapitan MC, Cody DJ, Grant AM. Open retropubic colposuspension for urinary incontinence in women [review]. Cochrane Database Syst Rev 2005;(3):CDoo2912.

28. Atherton MJ, Stanton SL. The tension-free vaginal tape reviewed: an evidencebased review from inception to current status. BJOG 2005;112:534-46.

29. Dwyer NT, Kreder KJ. An update on slings. Curr Opin Urol 2005;15:244-9.

30. Mellier G, Benayed B, Bretones S, et al. Suburethral tape via the obturator route: is the TOT a simplification of the TVT? Int Urogynecol J Pelvic Floor Dysfunct 2004; I5:227-32.

3I. De Tayrac R, Deffieux X, Resten A, et al. A transvaginal ultrasound study comparing 
transobturator tape and tension-free vaginal tape after surgical treatment of female stress urinary incontinence. Int Urogynecol J Pelvic Floor Dysfunct 2006;17:466-7I.

32. Fischer A, Fink T, Zachmann S, et al. Comparison of retropubic and outside-in transoburator sling systems for the cure of female genuine stress urinary incontinence. Eur Urol 2005;48:799-804.

33. Andersson KE, Hedlund P. Pharmacologic perspective on the physiology of the lower urinary tract. Urology 2002;60(5 Suppl I):13-20.

34. Diokno AC, Appell RA, Sand PK, et al. Prospective, randomized double-blind study of the efficacy and tolerability of the extended-release formulations of oxybutynin and tolterodine for overactive bladder: results of the OPERA trial. Mayo Clin Proc 2003;78:687-95.

35. Hay-Smith EJ, Bo Berghmans LC, Hendriks HJ, et al. Pelvic floor muscle training for urinary incontinence in women [review]. Cochrane Database Syst Rev 200I; (I):CDoor407.

36. Dmochowski RR, Davila GW, Zinner NR, et al; Transdermal Oxybutynin Study Group. Efficacy and safety of transdermal oxybutynin in patients with urge and mixed urinary incontinence. JUrol 2002;168:580-6.

37. Davila GW, Daugherty CA, Sanders SW, et al. A short-term multicenter, randomized double-blind dose titration study of the efficacy and anticholinergic side ef fects of transdermal compared to immediate release oral oxybutynin treatment of patients with urge urinary incontinence. JUrol 200I;166:140-5.

38. Dmochowski RR, Sand PK, Zinner NR, et al. Comparative efficacy and safety of transdermal oxybutynin and oral tolterodine versus placebo in previously treated patients with urge and mixed urinary incontinence. Urology 2003;62:237-42.

39. Chapple CR, Martinez-Garcia R, Selvaggi L, et al. for the STAR study group. A comparison of the efficacy and tolerability of solifenacin succinate and extended release tolterodine at treating overactive bladder syndrome: results of the STAR trial. Eur Urol 2005;48:464-70.

40. Kershen RT, Hsieh M. Preview of new drugs for overactive bladder and incontinence: darifenacin, solifenacin, trospium, and duloxetine. Curr Urol Rep 2004;5:359-67.

4I. Zinner N, Gittleman M, Harris R, et al. Trospium chloride improves overactive bladder symptoms: a multicenter phase III trial. JUrol 2004;I7I:23II-5.

42. Moriya H, Takagi $Y$, Nakanishi T, et al. Affinity profiles of various muscarinic antagonists for cloned human muscarinic acetylcholine receptor (mAChR) subtypes and $\mathrm{mAChRs}$ in rat heart and submandibular gland. Life Sci 1999;64:235I-8.

43. Yu YF, Nichol MB, Yu AP, et al. Persistence and adherence of medications fo chronic overactive bladder/urinary incontinence in the California Medicaid program. Value Health 2005;8:495-505.

44. Kelleher CJ, Cardozo LD, Khullar V, et al. A medium-term analysis of the subjective efficacy of treatment for women with detrusor instability and low bladder compli- ance. BrJ Obstet Gynaecol I997;104:988-93.

45. Moehrer B, Hextall A, Jackson S. Oestrogens for urinary incontinence in women [review]. Cochrane Database Syst Rev 2003;(2):CDoor405.

46. Chapple CR, Parkhouse H, Gardener C, et al. Double-blind, placebo-controlled, cross-over study of flavoxate in the treatment of idiopathic detrusor instability. $\mathrm{BrJ}$ Urol I990;66:49I-4.

47. Cvetkovic RS, Plosker GL. Desmopressin: in adults with nocturia [published erratum appears in Drugs 2005;65:1072]. Drugs 2005;65:99-107; discussion Io8-9.

48. Lose G, Mattiasson A, Walter S, et al. Clinical experiences with desmopressin for long-term treatment of nocturia. JUrol 2004;172:102I-5.

49. Smith CP, Chancellor MB. Emerging role of botulinum toxin in the management of voiding dysfunction. JUrol 2004;171:2128-37.

50. Romito S, Bottanelli M, Pellegrini M, et al. Botulinum toxin for the treatment of genital pain syndromes. Gynecol Obstet Invest 2004;58:164-7.

5I. Berghmans LC, Hendriks HJ, De Bie RA, et al.. Conservative treatment of urge urinary incontinence in women: a systematic review of randomized clinical trials. BJU Int 2000;85:254-63.

52. Bo K, Kvarstein B, Nygaard I. Lower urinary tract symptoms and pelvic floor muscle exercise adherence after I5 years. Obstet Gynecol 2005;105:999-I005.

53. Emmons SL, Otto L. Acupuncture for overactive bladder: a randomized controlled trial. Obstet Gynecol 2005;106:138-43.

54. Siegel SW, Catanzaro F, Dijkema HE, et al. Long-term results of a multicenter study on sacral nerve stimulation for treatment of urinary urge incontinence, urgency-frequency and retention. Urology 2000;56:87-91.

55. Schmidt RA, Jonas U, Oleson KA, et al. Sacral nerve stimulation for treatment of refractory urinary urge incontinence. J Urol I999;162:352-7.

56. Weil EH, Ruiz-Cerda JL, Eerdmans PH, et al. Sacral root neuromodulation in the treatment of refractory urinary urge incontinence: a prospective randomized clinical trial. Eur Urol 2000;37:I6I-7I.

57. Chaliha C, Khullar V. Mixed incontinence. Urology 2004;63(Suppl 3A):5I-7.

58. Dmochowski RR, Staskin D. Mixed incontinence: definitions, outcomes, and interventions. Curr Opin Urol 2005;15:374-9.

59. Paick JS, Ku JH, Shin JW, et al. Tension-free vaginal tape procedure for urinary incontinence with low Valsalva leak point pressure. J Urol 2004;172:1370-3.

\section{Correspondence to: Dr. Phillip P. Smith, Scott Department of}

Urology, Ste. 2100 Scurlock Tower, 6560 Fannin Ave., Houston TX 77030, USA; fax 713 798-5553; ppsmith@bcm.tmc.edu

\section{The complete} picture

\section{on research.}

\section{PRACTICAL. RELEVANT. CMAJ IS NOW MORE COMPREHENSIVE THAN EVER.}

CMAJ's reputation and wide Canadian and international reach make it THE place to publish leading Canadian research. CMAJ publishes important peer-reviewed research within weeks of submission and ranks fifth among international general medical journals by impact factor, a measure of the scientific importance of a journal.

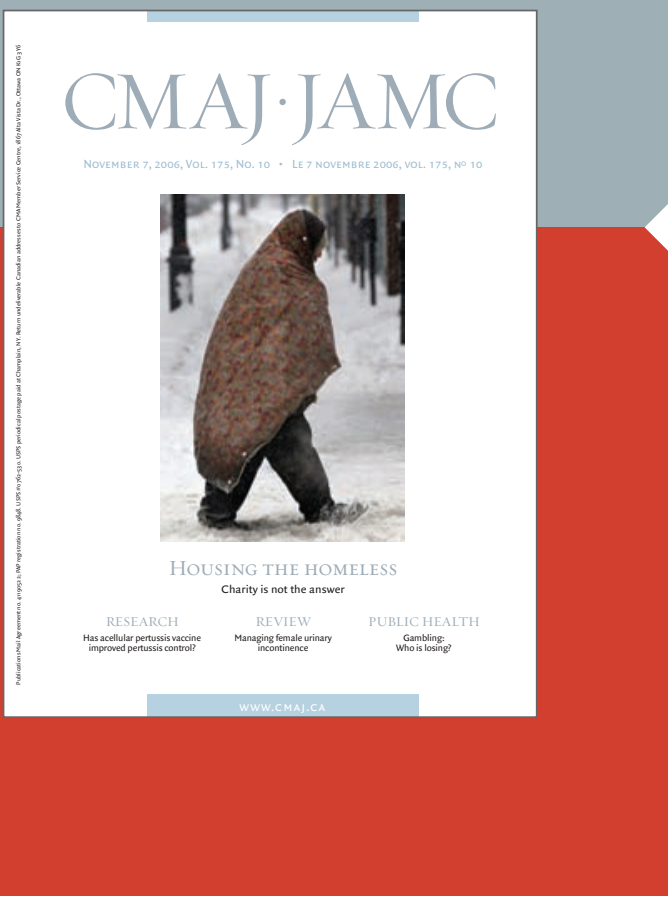

The essential read. ${ }^{\mathrm{T}}$ 